\title{
An Overview of Language Engagement: The Importance of Student Engagement for Second Language Acquisition
}

\author{
Zahra Mahdikhani (Corresponding author) \\ Dept. of English, Science and Research Branch, Islamic Azad University, Zanjan, Iran \\ E-mail: Mahdikhani_teacher@yahoo.com
}

Amir Rezaei

Assistant professor

English Language Department Islamic Azad University, Zanjan Branch, Zanjan, Iran

E-mail: rezaei.amirr@gmail.com

Received: May 7, 2015 Accepted: June 22, 2015 Published: June 24, 2015

doi:10.5296/jsel.v3i1.7891 URL: http://dx.doi.org/10.5296/jsel.v3i1.7891

\begin{abstract}
Student engagement has become a frequently used term in the vocabulary of Higher Education, and particularly among those involved in research associated with teaching and learning. It has been shown that despite the passage of time, the importance of engaging all students in their education continues to resonate strongly with families, students, educators, and researchers (Appleton, 2008). Student engagement in education has been gathering more and more attention; however, most of the studies in this field focus on the school engagement in general. It is currently argued among educators that student engagement is very significant concept, where individual differences between students in terms of their ability, cultural background and motivation are more considerable (Brown, 2005; Biggs, 2003; Prosser and Trigwell, 1999).

This study investigates the importance of language engagement in second language acquisition. One of the significant roles of engagement in language acquisition is its perspective on reading. Much research has focused on engagement and it is clear from these studies that as students are more engaged academic performance is hence improved.
\end{abstract}

Key words: student engagement, engaged reader, involvement, challenge 


\section{Introduction}

The phrases "student engagement" or "engagement in school " are often cited (Haymore, Ringstaff,\& Dwyer, 1994; Bangert-Drowns\& Pyke, 2001; Cumming\& Owen, 2001; Dodd, 1995; Finn, 1989; Fullarton, 2002; Linnenbrink \& Pintrich, 2002; Shernoff, Csikszentmihalyi, Schneider et al., 2003) as an essential component of programmatic interventions for students "at risk".

Fredericks, Blumenfeld, and Paris (2004) considered the potential of engagement as a meta construct and providing an opportunity to examine how these subsumed constructs interact. Nevertheless, Fredericks et al. (2004) also noted that there is considerable inconsistency in the concepts and terminology used across studies (see also Furlong et al., 2003; Jimerson, Campos, \& Greif, 2003). According to Zyngier (2008), student engagement has been identified as an important precursor to student learning. Engagement is now at the centre of mainstream education discussion and debate. Each discourse produces its own distinct understanding of what really defines student engagement. Coates (2007) holds that student engagement is a broad term, often perceived to encompass academic and non-academic features of the student learning experience, including active and collaborative learning or feeling supported by university learning communities.

According to Campbell, Voelkl, and Donahue (1997, online document), in the United States, a national sample of students at three ages $(9,13$, and 17 years) showed that the readers who were more engaged revealed higher achievement than the less engaged readers. In cross-age comparisons, 13-year-old students who were more engaged with reading achieved at a higher level than did 17-year-old students who were less engaged. Guthrie, Schafer, and Huang, (2001) stated Engaged readers can overcome obstacles to achievement and become agents of their own reading growth. Based on these views it can be said that engagement is strongly related to reading achievement.

If an engaged reader try to comprehend a text it's not only because she can do it, but because she is motivated to do it and may enjoy it. Oldfather and Dahl (1994) and Turner (1995) demonstrate students' enjoyment in reading for its own sake as essential to engaged reading. According to Csikszentmihalyi (1991), engaged reading is as a state of total absorption or "flow." Cambourne (1995) discuses that engagement is a merger of multiple qualities that entails holding a purpose, seeking to understand, believing in one's own capability, and taking responsibility for learning.

Guthrie, McGough, Bennett, and Rice (1996) believe that engaged readers are motivated, strategic, knowledgeable, and socially interactive. For a variety of personal goals engaged readers are motivated to read. They are strategic because of using multiple approaches to comprehend. They are knowledgeable for constructing new understanding from text. And they interact socially in their approach to literacy. Engaged readers can be considered as decision makers whose affects as well as their language and cognition play a role in their reading practices. 


\subsection{Engagement Theory}

Guthrie and Wigfield (2000), writing about engagement and motivation in reading, argue that a theoretical rational literacy research can be generated from worthy of investigation in engagement theory . Anderson and Guthrie (1996, p. 1) believe that engagement theory which was created to express children's motivation for the task of reading, falls under the wider umbrella of motivation theory which suggests that motivation is a multifaceted construct containing (but not limited to) values such as personal goal-setting, the desire and willingness to pursue a goal in the absence of external reinforcement, and "curiosity, social interchange, emotional satisfaction, and self-efficacy" .

Guthrie and Wigfield (2000) stated that engagement theory with a variety of descriptions, generally includes a vision of students who are eager to pursue the task at hand, actively involved in their work, and enjoy what they are doing which is similar to motivation theory. Guthrie and Wigfield (2000) suggested a definition of engaged readers as "engaged readers in the classroom or elsewhere coordinate their strategies and knowledge (cognition) within a community of literacy (social) in order to fulfill their personal goals, desires, and intentions (motivation)" (p. 404). This description can be helpful in visualizing how engaged students of vocabulary instruction might appear, But, it is not directly applicable because Guthrie and Wigfield's definition is specific to engaged readers rather than to engaged students on the whole.

\subsection{Definition of Engagement}

The construct of engagement is defined in general as involvement, participation, and commitment to some set of activities. It is currently argued that engagement can be defined as a reflection or manifestation of motivated action and noted that action incorporates emotions, attention, goals, and other psychological processes along with persistent and effortful behavior (Skinner, Kindermann, Connell, \& Wellborn, 2009a. According to Fredricks, Blumenfeld, and Paris (2004), school engagement contains behavioral, emotional, and cognitive aspects.

Appleton (2006) articulates engagement as having multiple components. Finn's (1989) model, demonstrate engagement as it is comprised of behavioral (participation in class and school) and affective components (school identification, belonging, valuing learning). Newmann, Wehlage, and Lamborn(1992) and Marks (2000) offered similar definitions. According to Fredericks et al. (2004), nevertheless, it can be concluded that engagement was comprised of three subtypes: behavioral (e.g., positive conduct, effort, participation), cognitive (e.g., self-regulation, learning goals, investment in learning), and emotional or affective (e.g., interest, belonging, and positive attitude about learning) (see also Jimerson, Campos, \& Greif, 2003).

\subsection{Student Engagement}

Appleton (2008) professes the view that engagement is a primary theoretical model for understanding drop out and is necessary to promote school completion and defines it as graduation from high school with sufficient academic and social skills to partake in post 
secondary enrollment options and/or the world of work (see also Christenson et al., 2008 and Finn, 2006). In fact sufficient engagement with school does not occur for far too many students.

According to Barton (2004), completing school with an appropriate set of skills is vital, and is even more significant as work positions with adequate compensation become increasingly less accessible to lower skilled applicants. In addition, Christenson et al. (2000) discusses that youth who do not complete high school are more likely to be incarcerated and experience long term dependency on social services. According to Sharkey et al. (2008), within academic literature, student engagement is often presented as a meta construct with two to four dimensions, containing behavioural, academic, psychological, and cognitive dimensions of engagement.

Previous research has established that in spite of a growing rhetoric about independent and autonomous learners (Thorpe, 2002) the teaching profession have no confidence that our students know how to learn best. Goodhew (2002) argues that how instead we offer them modularization and centralisation, a system where each topic has been packaged as a module which has been both delivered and examined within a single semester. These modules are centrally coordinated, and although wide choice exists in theory, teachers are able to screen out 'undesirable' students with numerous 'prerequisites' (where students have to have studied another module the previous year before accessing the module of choice).

Land and Bayne (2002) explains that when students engage with these offerings, there is no trust in their ability to complete them, leading to regimes of surveillance. Sinfield et al. (2004) expresses that the rhetoric of personalization and student centeredness constructs the individual learner primarily in the deficit, a shaving individual needs requiring individual support, and this hides and denies how people have been excluded from education because of their class or group position not because of individual flaws or lack of aspiration.

\subsection{Importance of Engagement in Learning}

Mosher \& MacGowan (1985) expresses that student engagement with school is significant, as is the observation that far too many students are bored, unmotivated, and uninvolved, that is, disengaged from the academic and social aspects of school life. Appleton, J. (2008) believes that laws may regulate the structure of the educational system, but student perspectives and experiences substantially influence academic and social outcomes.

Zyngier (2008) states that while many authors argue about student engagement, that it is "strongly related to achievement" (Guthrie, 2001) and that "there is considerable evidence in the research literature of the association between engagement and positive academic outcomes" (Fredericks et al., 2003), others maintain that engagement is not a predictor of academic success (Willms, 2003) and that while the prevalence of disengaged students varies between countries and among schools with in countries this is not attributable solely to family background, or to academic achievement.

Willms (2003, p. 11) stated that while the " contextual affects" of school are important, a high percentage of minority or low socioeconomic status students in a school led to higher 
dropout, but not necessarily disengagement Schlechty $(2001,2002)$ on the other hand, found that even such students who with draw or retreat from school learning and activities are making conscious decisions about their schooling.

Likewise, Bangert Drowns et al. (2001 \& 2002) in attempting a taxonomy of engagement view student engagement as a multifaceted and complex concept, arguing that engagement can also be problematic, unsystematic or even frustrated as well as structured, self regulated, literate and finally critical.

Newmann (1992), developing an increasingly complex understanding of engagement, identifies the factors that affect engagement in academic work as (i) school membership (clarity of purpose, fairness, personal support, success and caring) and (ii) authentic work (extrinsic rewards, intrinsic interests, sense of owner ship, connection to real world and fun (Newmann, 1992, p. 18)).

Haberman (1991) believes that even with exciting material, students may remain apathetic. According to Dodd (1995, p. 65), what is needed to engage students is not necessarily learning that is fun, but learning over which they have ownership; that empowers them to make a difference to their lives.

\subsection{Engagement Perspective on Reading}

According to the engagement perspective on reading, which was developed by Guthrie and Wigfield (2004), classroom instructional practices connects to students' motivations, strategy use, conceptual knowledge, and social interactions, and ultimately to their reading outcomes. Based on this engagement perspective, students' motivation includes multifaceted aspects such as goals, intrinsic and extrinsic motivation, values, self-efficacy, and social motivation.

These motivational aspects of the reader propel students to choose to read and to use cognitive strategies to comprehend. The strategies in the model refer to students' multiple cognitive processes of comprehending, self-monitoring, and constructing their understanding and beliefs during reading. Conceptual knowledge refers to the notion that reading is knowledge-driven. Social interactions include collaborative practices in a community and the social goals of helping other students or cooperating with a teacher. These in turn influence students' reading achievement, knowledge gained from reading, and the kinds of practices in which they engage.

\section{Conclusion}

It is clear from the literature that as schools become more effective, students are more engaged and academic performance is hence improved. Greater student engagement is assign therefore of effective schooling or school improvement. Such studies seek to establish a strong relationship between engagement and performance, such that student participation leads to academic success "across diverse populations" and that engagement has a "consistent, strong correlation with academic performance" and also race/ethnicity and socioeconomic status (Finn, 1989,p. 118; Finn, Pannozzo, \& Achilles, 2003, pp. 323-324). 
According to Marks (2000, p. 171), socioeconomic status consistently predicts engagement form idle school students reinforcing the conclusion of the QSRLS (Lingard et al, 2001a, b) and Schlechty (2002) concludes that while middle class students and middle class schools have a higher overall engagement and academic success, it seems also that the longer a student stays at school the lower is their engagement. This view that there is equivalence and correlation between student engagement and academic success is now addressed.

This review also, identifies the classification of engagement (i.e., behavioural, academic, psychological, and cognitive engagement) and puts forward that these do not necessarily lead to the same outcomes. For example, Shernoff and Schmidt $(2006,2008)$ state that behavioural, academic, and psychological engagement appear related to positive social outcomes, it is questionable if they lead to increased learning for all students as engagement/ achievement paradoxes have been found.

\section{References}

Anderson, E., \& Guthrie, J. (1996). Teaching with CORI: Taking the big jump. NRRC News. Newsletter of the National Reading Research Center. Athens, GA: NRRC.

Appleton, J. J., Christenson, S. L., \& Furlong, M. J. (2008). Student engagement with school: Critical conceptual and methodological issues of the construct. Psychology in the Schools, 45, 369-386.

Appleton, J. J., Christenson, S. L., Kim, D., \& Reschly, A. L. (2006). Measuring cognitive and psychological engagement: Validation of the Student Engagement Instrument. Journal of School Psychology, 44, 427-445.

Bangert-Drowns, R. L., \& Pyke, C. (2001). A taxonomy of student engagement with educational software: An exploration of literate thinking with electronic text. Journal of Educational Computing Research, 24(3), 213-234.

Bangert-Drowns, R. L., \& Pyke, C. (2002). Teacher ratings of student engagement with educational software: An exploratory study. Educational Technology Research and Development, 50(2), 23-38.

Barton, P. E. (2004).One-third of a nation: Rising dropout rates and declining opportunities. Princeton, NJ: Policy Information Center, Educational Testing Servise.

Biggs, J. B. (2003) Teaching for Quality Learning at University (2nd edition), Buckingham: SRHE and Open University.

Brewster, A., \& Bowen, G. (2004). Teacher support and school engagement of Latino middle and high school students at risk of school failure. Child and Adolescent Social Work Journal, 21(1), 47-67.

Brown, S. (2005) Assessment for learning. Learning and Teaching in Higher Education, 1, 81-89, available at http://www.glos.ac.uk/tli/lets/journals/lathe/issue1/index.cfm (accessed 23/7/2007). 
Cambourne, B. (1995). Toward an educationally relevant theory of literacy learning: Twenty years of inquiry. Reading Teacher, 49, 182-192.

Campbell, J. R., Voelkl, K. E., \& Donahue, P.L. (1997). NAEP 1996 trends in academic progress (NCES Publication No. 97985r). Washington, DC: U.S. Department of Education. Available: nces.ed.gov/pubsearch/pubsinfo.asp?pubid=97985r

Csikszentmihalyi, M. (1991). Literacy and intrinsic motivation. In S.R. Graubard (Ed.), Literacy (pp. 115-140). New York: Noonday.

Christenson, S. L., Reschly, A. L., Appleton, J. J., Berman, S., Spangers, D., \& Varro, P. (2008). Best practices in fostering student engagement. In A. Thomas \& J. Grimes (Eds.), Best practices in school psychology $V$ (pp. 1099-1120). Washington, DC: National Association of School Psychologists.

Christenson, S. L., Sinclair, M. F., Lehr, C. A., \& Hurley, C. M. (2000). Promoting successful school completion. In D. Minke \& G. Bear (Eds.), Preventing school problems-promoting school success: Strategies and programs that work (pp. 377-420). Bethesda, MD: National Association of School Psychologists.

Coates, H. (2007) A model of online and general campus-based student engagement. Assessment and Evaluation in Higher Education, 32(2), 121-141.

Connell, J. P., \& Wellborn, J. G. (1991). Competence, autonomy, and relatedness: A motivational analysis of self-system processes. In M. R. Gunnar \& L. A. Sroufe (Eds.), Self processes and development (Vol. 23, pp. 43-77). Hillsdale, NJ: Lawrence Erlbaum.

Cothran, D. J., \& Ennis, C. D. (2000). Building bridges to student engagement: communicating respect and care for students in urban high schools. Journal of Research and Development in Education, 33(4), 106-117.

Cumming, J., \& Owen, C. (2001). Reforming Schools through Innovative Teaching, Australian College of Educators, Enterprise and Career Education Foundation and Dusseldorp Skills Forum, ACE Canberra.

Dodd, A. W. (1995). Engaging students: What I learned along the way. Educational Leadership, 53(1), 65-67.

Finn, J. D. (1989). Withdrawing from school. Review of Educational Research, 59, 117-142.

Finn, J. D. (2006). The adult lives of at-risk students: The roles of attainment and engagement in high school (NCES2006-328). Washington, DC: U.S. Department of Education, National Center for Education Statistics.

Finn, J., \& Voelk1, K. (1993). School characteristics related to student engagement. Journal of Negro Education, 62(3), 249-268.

Finn, J. D., Pannozzo, G. M., \& Achiles, C. M. (2003). The 'why's' of class size: student behaviour in small classes. Review of Educational Research, 73(3), 321-368. 
Fredericks, J., Bluemnfeld, P., Friedel, J., \& Paris, A. (2003). In School engagement, indicators of positive development conference, Washington, DC, 11-13 March.

Fredricks, J. A., Blumenfeld, P. C., \& Paris, A. H. (2004). School engagement: Potential of the concept, state of the evidence. Review of Educational Research, 74, 59-109.

Fullarton, S. (2002). Student engagement with school: Individual and school-level influences (No. 27, Longitudinal Surveys of Australian Youth Research Report). Camberwell, Victoria: Australian Council for Educational Research (ACER).

Furlong, M. J., \& Christenson, S. L. (2008). Engaging students at school and with learning: A relevant construct for ALL students. Psychology in the Schools, 45(5), 365-368.

Furlong, M. J., Whipple, A. D., St. Jean, G., Simental, J., Soliz, A., \& Punthuna, S. (2003). Multiple contexts of schoolengagement:Moving toward a unifying framework for educational research and practice. California School Psychologist, 8, 99-114.

Goodhew, P. (2002). Modularisation and sliced bread, higher education academy discussion paper. http://www.materials.ac.uk/discuss/modularisation.asp Accessed 31.07.09.

Guthrie, J. T. (2001). Contexts for engagement and motivation in reading. Reading Online, 4(8). http://www.readingonline.org/articles/art_index.asp?HREF $1 / 4 /$ articles/handbook/Guthrie /index.htmlS.

Guthrie, J. T., \& Wigfi eld, A. (2000). Engagement and motivation in reading. In M. L. Kamil, \& P. B. Mosenthal (Eds.), Handbook of reading research (Vol. III, pp. 403- 422). Mahwah, NJ: Erlbaum.

Guthrie, J. T., Wigfield, A., \& Perencevich, K. C. (Eds.). (2004). Motivating reading comprehension: Concept-Oriented Reading Instruction. Mahwah, NJ: Erlbaum.

Guthrie, J. T., McGough, K., Bennett, L., \& Rice, M. E. (1996). Concept-oriented reading instruction: An integrated curriculum to develop motivations and strategies for reading. In L. Baker, P. Afflerbach, \& D. Reinking (Eds.), Developing engaged readers in school and home communities (pp. 165- 190). Hillsdale, NJ: Erlbaum.

Guthrie, J.T., Schafer, W.D., \& Huang, C. (2001). Benefits of opportunity to read and balanced reading instruction for reading achievement and engagement: A policy analysis of state NAEP in Maryland. Journal of Educational Research, 94(3), 145-162.

Haberman, M. (1991). The pedagogy of poverty versus good teaching. Phi Delta Kappan, 73(4), 290-294.

Haymore, J., Ringstaff, C., \& Dwyer, D. C. (1994). Student Engagement: Views from Technology-Rich Classrooms, Apple Computer Inc.

Jimerson, S. R., Campos, E., \& Greif, J. L. (2003). Toward an understanding of definitions and measures of school engagement and related terms. California School Psychologist, 8, $7-27$. 
Land, R., \& Bayne, S. (2002). Screen or monitor? Surveillance and disciplinary power in online learning environments. In C. Rust (Ed.), Improving student learning through technology. Oxford: Oxford Centre for Staff Development.

Lingard, B., Ladwig, J., et al. (2001a). Queensland School Reform Longitudinal Study.

Lingard, B., Ladwig, J., et al. (2001b). Queensland School Reform Longitudinal Study: Supplementary Materials, Brisbane.

Linnenbrink, E. A., \& Pintrich, P. R. (2002). Motivation as an enabler for academic success. School Psychology Review, 31(3), 313-327.

Marks, H. M. (2000). Student engagement in instructional activity: Patterns in elementary, middle and high school years. American Educational Research Journal, 37, 153-184.

McFadden, M., \& Munns, G. (2002). Student engagement and the social relations of pedagogy. British Journal of Sociology of Education, 23(3), 357-366.

Mosher, R., \& McGowan, B. (1985). Assessing student engagement in secondary schools: Alternative conceptions, strategiesof assessing, and instruments. University of Wisconsin, Research and Development Center. (ERIC DocumentReproduction Service No. ED 272812).

Newmann, F. (1992). Higher-order thinking and prospects for classroom thoughtfulness. In F. Newmann (Ed.), Student engagement and achievement in Americansecondary schools (pp. 62-91). New York, USA: Teachers College Press.

Newmann, F., Wehlage, G., \& Lamborn, S. D. (1992). The significance and sources of student engagement. In F. Newmann (Ed.), Student engagement and achievement in American secondary schools (pp. 11-39). New York, USA: Teachers College Press.

Oldfather, P., \& Dahl, K. (1994). Toward a social constructivist reconceptualization of intrinsic motivation for literacy learning. Journal of Reading Behavior, 26, 139-158.

Prosser, M., \& Trigwell, K. (1999) Understanding Learning and Teaching: The Experience in Higher Education, Buckingham. SRHE and Open University Press.

Schlechty, P. C. (2002). Working on the work: An action plan for teachers, principals, and superintendents. San Francisco: Jossey-Bass.

Sharkey, J. D., Sukkyung, Y., \& Schnoebelen, K. (2008). Relations among school assets, individual resilience, and student engagement for youth grouped by level of family functioning. Psychology in the Schools, 45(5), 402-418.

Sharkey, J. D., Sukkyung, Y., \& Schnoebelen, K. (2008). Relations among school assets, individual resilience, and student engagement for youth grouped by level of family functioning. Psychology in the Schools, 45(5), 402-418.

Shernoff, D. J., Csikszentmihalyi, M., Schneider, B., \& Shernoff, E. (2003). Student Engagement in High School Classrooms from the Perspective of Flow Theory. School Psychology Quarterly, 18(2), 158-176. 
Shernoff, D. J., \& Schmidt, J. (2006, March). Evidence and explanations for an engagement-achievement paradox among high school students. Invited lecture presented to the Center for Research on Educational Opprtunity, University of Notre Dame, South Bend, IN.

Shernoff, D. J., \& Schmidt, J. (2008), Further evidence of an engagement achievement paradox among U.S. High school students. Journal of Youth and Adolescence, 37, 564-580.

Sinfield, S., Burns, T., \& Holley, D. (2004). Outsiders looking in or insiders looking out? Widening participation in a post-1992 University. In J. Satterthwaite, E. Atkinson, \& W. Martin (Eds.), The discipline of education: New languages of power and resistance. Stoke on Trent: Trentham Books.

Skinner, E. A., \& Belmont, M. J. (1993). Motivation in the classroom: Reciprocal effects of teacher behavior and student engagement across the school year. Journal of Educational Psychology, 85, 571-581.

Thorpe, M. (2002). Rethinking learner support: The challenge of collaborative online learning. Open Learning, 7(2), 105-120.

Turner, J. C. (1995). The influence of classroom contexts on young children's motivation for literacy. Reading Research Quarterly, 30, 410-441.

Willms, J. D. (2003). Student Engagement at School: A Sense of Belonging and Participation. Results from PISA 2000. Paris: Organization for Economic Co-operation and Development (OECD). Accessed October 2010, 56.

Zyngier, D. (2008). (Re)conceptualising student engagement: doing education not doing time. Teaching and Teacher Education, 24, 1765-1776.

\section{Copyright Disclaimer}

Copyright for this article is retained by the author(s), with first publication rights granted to the journal.

This is an open-access article distributed under the terms and conditions of the Creative Commons Attribution license (http://creativecommons.org/licenses/by/3.0/). 